\title{
Flexible Yttrium-Stabilized Zirconia Nanofibers Offer Bioactive Cues for Osteogenic Differentiation of Human Mesenchymal Stromal Cells
}

Citation for published version (APA):

Gazquez, G. C., Chen, H., Veldhuis, S. A., Solmaz, A., Mota, C. M. D., Boukamp, B. A., van Blitterswijk, C. A., ten Elshof, J. E., \& Moroni, L. (2016). Flexible Yttrium-Stabilized Zirconia Nanofibers Offer Bioactive Cues for Osteogenic Differentiation of Human Mesenchymal Stromal Cells. ACS Nano, 10(6), 5789-5799. https://doi.org/10.1021/acsnano.5b08005

Document status and date:

Published: 01/06/2016

DOI:

10.1021/acsnano.5b08005

Document Version:

Publisher's PDF, also known as Version of record

Document license:

Taverne

Please check the document version of this publication:

- A submitted manuscript is the version of the article upon submission and before peer-review. There can be important differences between the submitted version and the official published version of record.

People interested in the research are advised to contact the author for the final version of the publication, or visit the DOI to the publisher's website.

- The final author version and the galley proof are versions of the publication after peer review.

- The final published version features the final layout of the paper including the volume, issue and page numbers.

Link to publication

\footnotetext{
General rights rights.

- You may freely distribute the URL identifying the publication in the public portal. please follow below link for the End User Agreement:

www.umlib.nl/taverne-license

Take down policy

If you believe that this document breaches copyright please contact us at:

repository@maastrichtuniversity.nl

providing details and we will investigate your claim.
}

Copyright and moral rights for the publications made accessible in the public portal are retained by the authors and/or other copyright owners and it is a condition of accessing publications that users recognise and abide by the legal requirements associated with these

- Users may download and print one copy of any publication from the public portal for the purpose of private study or research.

- You may not further distribute the material or use it for any profit-making activity or commercial gain

If the publication is distributed under the terms of Article 25fa of the Dutch Copyright Act, indicated by the "Taverne" license above, 


\section{AGNANO}

\section{Flexible Yttrium-Stabilized Zirconia Nanofibers Offer Bioactive Cues for Osteogenic Differentiation of Human Mesenchymal Stromal Cells}

Gerard Cadafalch Gazquez, ${ }^{\dagger, \S}$ Honglin Chen, $^{\ddagger}, \S$ Sjoerd A. Veldhuis, ${ }^{\dagger}$ Alim Solmaz, ${ }^{\dagger}$ Carlos Mota, ${ }^{\dagger}$ Bernard A. Boukamp, ${ }^{\dagger}$ Clemens A. van Blitterswijk, Johan E. ten Elshof, $*^{\dagger}$ and Lorenzo Moroni*,

${ }^{\dagger}$ Inorganic Materials Science Group, MESA+ Institute for Nanotechnology, University of Twente, 7500 AE Enschede, The Netherlands

${ }^{\ddagger}$ Department of Complex Tissue Regeneration, MERLN Institute for Technology Inspired Regenerative Medicine, 6200 MD Maastricht, The Netherlands

\section{Supporting Information}

ABSTRACT: Currently, the main drawback of ceramic scaffolds used in hard tissue regeneration is their low mechanical strength. Stabilized zirconia, especially the tetragonal $3 \%$ yttrium-stabilized zirconia (YSZ) phase, has been considered as a bioinert ceramic material with high mechanical strength. In the present work, flexible nanofibrous YSZ scaffolds were prepared by electrospinning. The obtained scaffolds showed remarkable flexibility at the macroscopic scale, while retaining their stiffness at the microscopic scale. The surface nanoroughness of the scaffolds could be tailored by varying the heat treatment method. Our results demonstrate that the osteogenic differentiation and mineralization of seeded human mesenchymal stromal cells were supported by the nanofibrous YSZ scaffolds, in contrast to the well-known bioinert behavior of bulk YSZ. These findings highlight that flexible ceramic scaffolds are an appealing alternative to the current brittle ceramics for bone tissue regeneration applications.

KEYWORDS: flexible ceramic scaffolds, electrospinning ceramic, surface roughness, human mesenchymal stromal cells, osteogenic differentiation

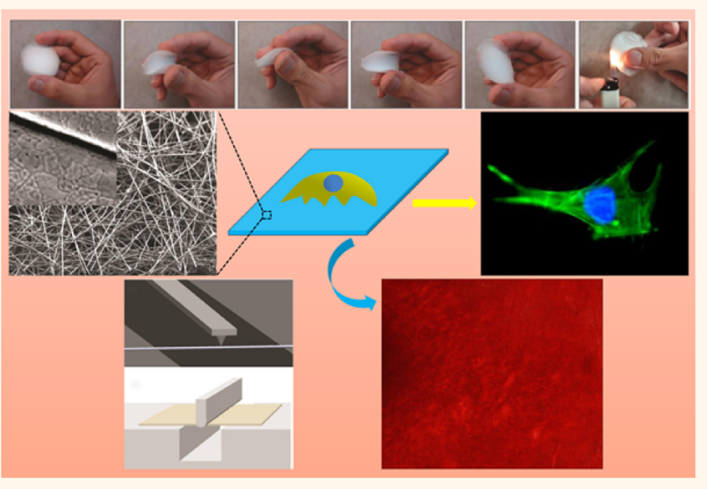

$\mathrm{B}$ ioceramics have been widely used for several decades to repair bone damage, ${ }^{1-3}$ since they are promising materials due to their similarity to bone in terms of chemical properties. ${ }^{4-7}$ Within the area of bioceramics, a clear distinction is made between bioinert and bioactive materials. Bioinert ceramics can be defined as those that do not bond with the surrounding tissues nor induce a cell response. Examples of bioinert materials are alumina and yttria-stabilized zirconia (YSZ). ${ }^{2,3}$ Conversely, bioactive ceramics are materials that can actively induce a specific cell response (e.g., cell differentiation) and, in some cases, are resorbable. These materials include hydroxyapatite (HA), $\beta$-calcium phosphates, and bioactive glasses. $^{1-3}$ One of the major limitations of ceramic scaffolds for hard tissue regeneration is that they suffer from low mechanical strength, which may facilitate fragile failure when implanted. ${ }^{4,6,8}$ Among the aforementioned bioceramic materials, zirconia has the highest mechanical strength, especially the $3 \%$ yttriumstabilized tetragonal zirconia (YSZ) phase. ${ }^{9,10}$
The scaffold's microstructure also plays a crucial role. Microporosity provides a large surface area for cell adhesion, thus improving the biological response. ${ }^{11}$ However, the scaffolds' mechanical properties are negatively affected. ${ }^{4,7}$ Porosity reduces the mechanical strength of materials.? Tailor-made design of the nanoarchitecture of porous biomaterials may help to overcome these issues. ${ }^{9,12-14}$ A recent study demonstrated a nanoarchitectured aluminosilicate ceramic with improved ductility and flexible recovery after compressive stresses. ${ }^{12}$ Nanofiber mats of titania, silica, and zirconia with enhanced flexibility have also been reported. ${ }^{13-20}$

To fabricate scaffolds with fiber dimensions on the nano- to microscale mimicking the features of the natural extracellular

Received: December 18, 2015

Accepted: June 13, 2016

Published: June 13, 2016 

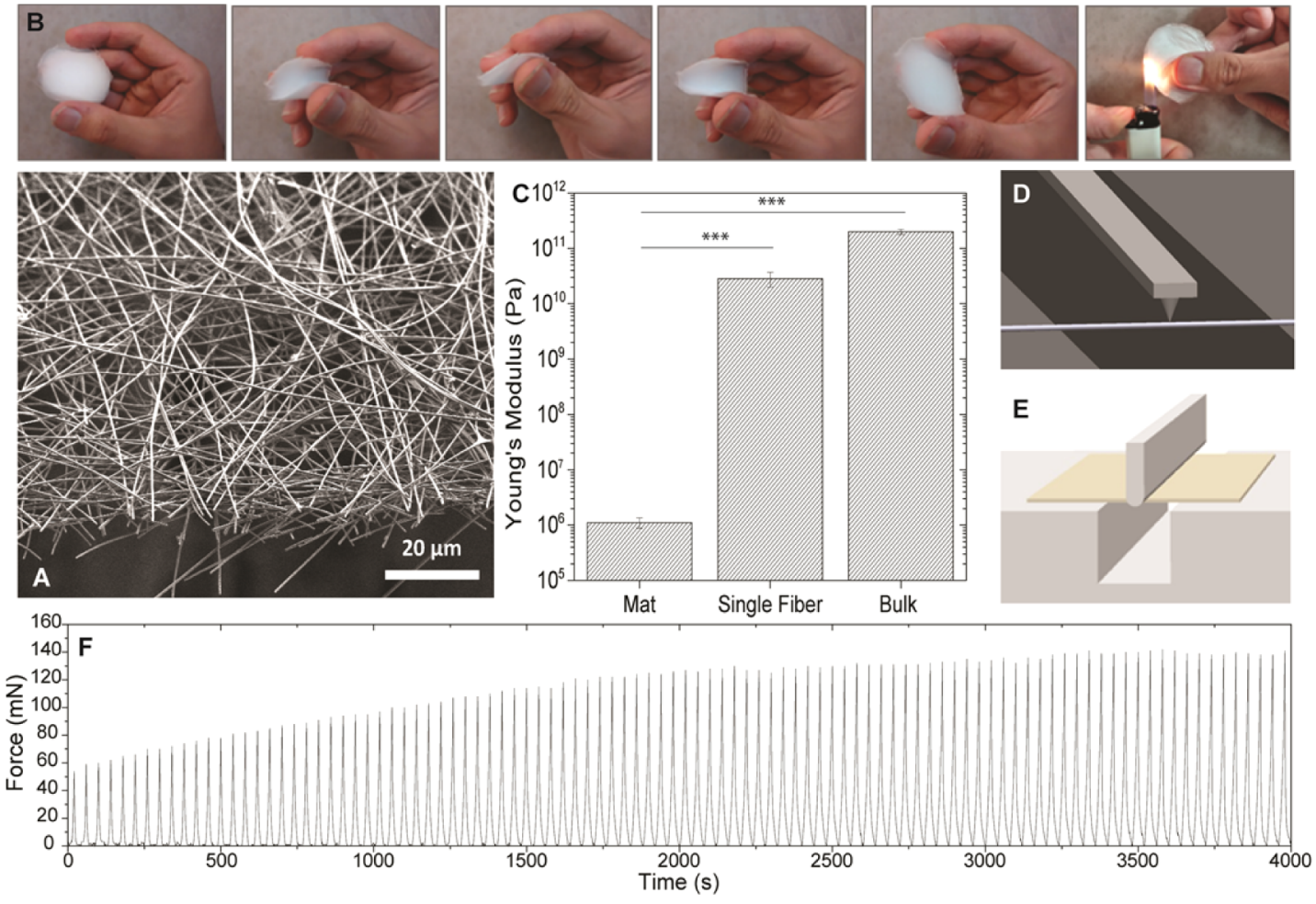

Figure 1. Flexibility of YSZ nanofiber mats. (A) SEM images of a YSZ nanofiber mat; scale bar is $20 \mu \mathrm{m}$. (B) Pictures of the YSZ mat showing its flexibility and fire resistance ceramic nature. (C) Mechanical properties of a nanofiber mat by microindentation (at macroscopic scale), a single nanofiber by three-point bending using AFM (at microscopic scale and bulk YSZ (taken from literature). ${ }^{27-29}$ (D) Schematic overview of a three-point bending test on a single nanofiber using AFM. (E) Schematic illustration of a three-point bending fatigue test on the nanofiber mat. (F) Representative histogram of 200 cycles of the three-point bending fatigue test on a YSZ nanofiber mat in which the force was monitored as a function of time. Error bars represent standard deviation of the mean. The statistical significance was determined using a one way ANOVA test, where $* * * p<0.001$.

matrix (ECM), electrospinning has been used broadly to fabricate scaffolds for regenerative medicine. ${ }^{21-23}$ Cells respond to chemical and physical stimuli from their neighboring cells as well as from the surrounding fluid and ECMs. ${ }^{24}$ The characterization and control of surface properties, such as surface roughness, can therefore be used to optimize cell attachment, proliferation, and differentiation.

In this article, we propose the fabrication of a flexible YSZ nanofiber material for bone tissue engineering. Recently, YSZbased fibers have been fabricated by electrospinning for various application, such as fuel cells ${ }^{25}$ and filtration, ${ }^{18}$ but their use in the biological and biomedical field has not been explored to our knowledge. Herein, we introduce flexible YSZ ceramic nanofibers in the field of regenerative medicine. The YSZ fibers typically have lengths of the order of meters, instead of just a few millimeters as reported earlier, ${ }^{25}$ and a high gravimetric density. The sintering temperature that we employed to densify the ceramic nanofibers was much lower than in earlier studies, ${ }^{25}$ so that sintering between fibers was avoided, which contributed further to their flexibility and retention of mechanical properties upon cyclic deformation. Indeed, these YSZ ceramic nanofibers have remarkable flexibility compared to traditional bioactive ceramics, and their surface nanoroughnesses can be tailored for cellular response. Interestingly, in contrast to the well-known bioinert behavior of bulk YSZ, nanofiber meshes support in vitro osteogenic differentiation and mineralization of human mesenchymal stromal cells (hMSCs). This is the first study showing that flexible YSZ ceramic fibers with tailored surface nanoroughness can conduct osteogenic differentiation of hMSCs. The flexibility of the scaffold helps to overcome the problem of the fragile fracture that is characteristic for traditional bioceramic scaffolds. Therefore, it provides a complement to the currently available library of bioactive ceramic materials for bone tissue regeneration.

\section{RESULTS AND DISCUSSION}

The ceramic nanofibers were fabricated by electrospinning with a mixture of a YSZ precursor and polyvinylpyrrolidone (PVP). Subsequently, the resulting fiber mats were annealed by means of conventional or microwave-assisted heating in static air at $850{ }^{\circ} \mathrm{C}$ for $2 \mathrm{~h}$ using different heating rates (i.e., to burn out the organic phases and for crystalline phase formation). The obtained nanofibers had a diameter of $530 \pm 120 \mathrm{~nm}$ (Figure S1), and the fiber mats had a thickness of approximately 120 $\mu \mathrm{m}$. A scanning electron microscopy (SEM) image of the material is shown in Figure 1A. The YSZ nanofiber mats exhibited extraordinary flexibility not often demonstrated for pure ceramic materials. It behaved as a paper-like material (Figure $1 \mathrm{~B}$ and Video S1). The material could achieve total deflection $\left(180^{\circ}\right.$ bending) without mechanical failure. Moreover, the deflection could be cycled at least 1000 times without breaking the material when a three-point bending test was performed. To the best of our knowledge, the fabrication of ceramic nanofiber mats with such high flexibility and good fatigue behavior has not been reported until now. The flexibility of electrospun silica-based mats has been attributed to the amorphous nature of the material, which is therefore more 
robust than crystalline materials. ${ }^{14,26}$ However, that hypothesis does not explain the behavior of the crystalline YSZ nanofibers reported here (X-ray diffractograms showing crystalline nature are shown in Figure S2). Park et al. hypothesized that the flexibility of crystalline $\mathrm{TiO}_{2}$ was the result of the physical entanglement as single nanofibers are brittle. ${ }^{13}$ However, we observed that also single nanofibers were able to withstand a high degree of deflection (Video S2). Probably due to the long length of the nanofibers, the mechanical energy could be dissipated under the elastic deflection. The coherence of fibers mats composed of long fibers is better than that of fiber mats composed of an assembly of fiber fragments. Moreover, the sintering temperature of $850{ }^{\circ} \mathrm{C}$ that we employed is much lower than in earlier reports on YSZ nanofibers where a temperature of $1500{ }^{\circ} \mathrm{C}$ was used. ${ }^{25}$ As a result, our YSZ fibers densified but did not sinter together, which contributes to their freedom of movement and thus to their flexibility and makes them less susceptible to fatigue-like phenomena. The flexibility of the mat was further quantified by microindentation tests. The Young's modulus of the material was $1.11 \pm 0.24 \mathrm{MPa}$, more than 5 orders of magnitude lower than that of bulk YSZ (Figure 1C), which is in the range of 178-222 GPa according to literature data. ${ }^{9,27-29}$ We also measured the mechanical properties of single nanofibers by a three-point bending test using atomic force microscope (AFM) (Figure 1D). The measured apparent Young's modulus of a single fiber was $30 \pm$ $3 \mathrm{GPa}$, and a high deflection angle could be achieved. The apparent Young's modulus of single fibers was several orders of magnitude higher than the macroscopic mat, but still a factor of 7 lower than bulk YSZ (Figure 1C). This result is in accordance with other studies on electrospun ceramic nanofibers, which report similar decreases in Young's modulus when measured via a three-point bending test using AFM. ${ }^{30,31}$ The diameter and mechanical properties of the nanofibers at the different length scales did not vary significantly with the annealing treatment (Figure S3).

A special setup was designed to perform a three-point bending fatigue test on the mat (Figure $1 \mathrm{E}$ ). The experiment consisted of 200 cycles of $45^{\circ}$ deflection, while the applied force was monitored (Figure 1F). The sample did not break, and to our surprise we observed a slight increase of the force necessary to deflect the sample. Chen et al. reported slipping of individual nanofibers under tensile stress. ${ }^{18}$ It may be possible that such a phenomenon occurs during deflection, gradually leading to a rearrangement of the fibers with an increasing number of cycles, ultimately resulting in a slightly stiffer material.

Moreover, the nanofibers mat offered a very low density, in the range of $0.06-0.09 \mathrm{~g} / \mathrm{cm}^{3}$. Based on SEM observations, i.e., the absence of pores and grain boundaries, each individual fiber can be considered as nearly dense. The Young's moduli of the nanofiber mats and individual fibers were plotted vs the density, as shown in Figure 2. For comparison, the values of other traditional materials were also plotted. It can be seen that the ceramic nanofibers mat behaved like a foam in terms of stiffness and density. This means that it is lighter and more flexible than other polymers, ceramics, and porous ceramics. Nevertheless, individual nanofibers offer stiffness values close to ceramics and typical of porous ceramics or metals, 5 orders of magnitude stiffer than the mat.

The surface morphology and grain size of the fibers were modified by annealing the samples under different conditions. The green fiber mats were annealed in a conventional oven

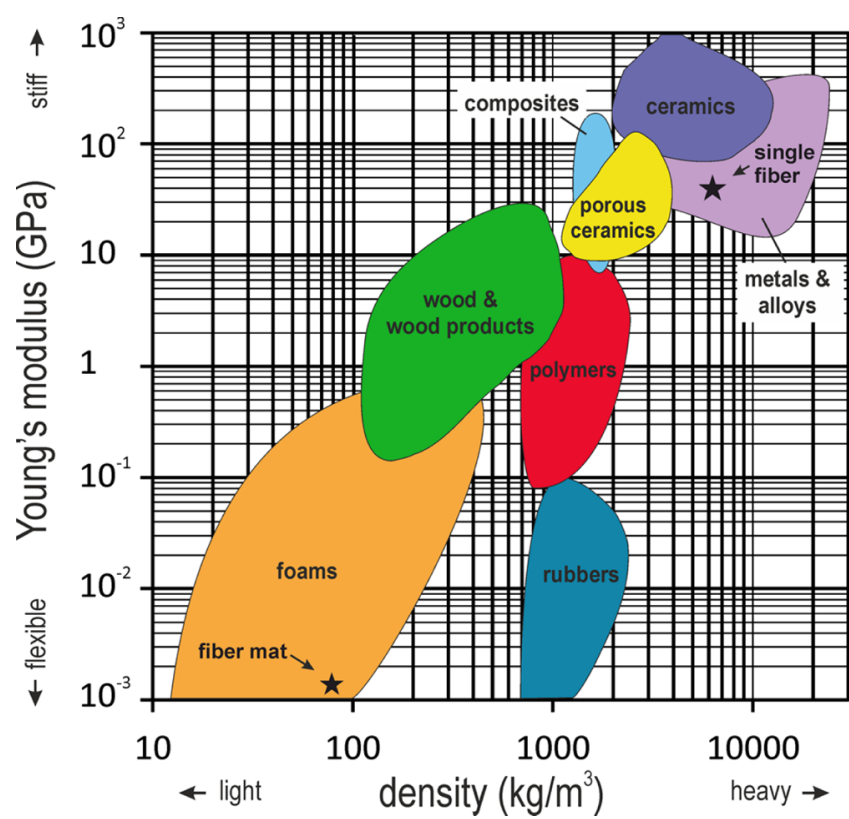

Figure 2. Plot of Young's modulus vs density. The nanofiber mat and single nanofiber are compared with other traditional materials.

(CO) at 1 or $5{ }^{\circ} \mathrm{C} / \mathrm{min}$ heating rate and in a microwave oven (MW) at $5{ }^{\circ} \mathrm{C} / \mathrm{min}$ or by rapid thermal annealing (i.e., thermal shock). Rapid thermal annealing (RTA) is a method in which the MW is preheated to $850{ }^{\circ} \mathrm{C}$ prior to placing the sample in the oven. The samples annealed in the $\mathrm{CO}$ showed rougher surface morphologies than the samples annealed in the MW even at the same heating rate, as shown by SEM (Figure 3A) and AFM (Figure 3B) analysis. This was further confirmed by the statistical analysis performed on the roughness data (Figure 3C). However, varying the heating rate did not result in significant differences among samples that were annealed by the same heating mechanism. The samples annealed in the $\mathrm{CO}$ at 1 and $5{ }^{\circ} \mathrm{C} / \mathrm{min}$ had roughnesses of $0.8 \pm 0.3$ and $0.7 \pm 0.2 \mathrm{~nm}$, respectively. Both samples annealed in the $\mathrm{MW}$ had a roughness of $0.4 \pm 0.1 \mathrm{~nm}$. The heating mechanism had a significant influence on surface roughness. Samples annealed at $5{ }^{\circ} \mathrm{C} / \mathrm{min}$ in a $\mathrm{CO}$ had a rougher surface than the samples annealed in a MW at the same heating rate $(0.7 \pm 0.2 \mathrm{~nm}$ vs 0.4 $\pm 0.1 \mathrm{~nm})$. These results were consistent with the surface morphologies in SEM images (Figure 3A). However, it is noted that the roughness with AFM is measured in the out-of-plane direction, whereas the SEM images shows in-plane features of surface morphology. Different grain sizes were observed for each heating rate (Figure 3D), as calculated from the full width at half-maximum (fwhm) in the XRD patterns (Figure S2). Samples annealed in the $\mathrm{CO}$ at $1{ }^{\circ} \mathrm{C} / \mathrm{min}$ had the largest grain size $(24 \pm 1 \mathrm{~nm})$. Samples annealed in the CO and MW at 5 ${ }^{\circ} \mathrm{C} / \mathrm{min}$ had intermediate grain sizes of $22 \pm 1$ and $18 \pm 1 \mathrm{~nm}$, respectively. The sample annealed in the MW using RTA had a much smaller grain size of $9.5 \pm 0.1 \mathrm{~nm}$. The samples annealed using lower heating rates showed larger grain sizes, irrespective of the heating mechanism. This can be attributed to the longer effective sintering times at high temperature under such conditions. The heating mechanism also affected the grain size. The samples annealed at $5{ }^{\circ} \mathrm{C} / \mathrm{min}$ in a $\mathrm{CO}$ had a larger grain size than the samples annealed in a $\mathrm{MW}$ at the same heating rate. YSZ has previously been reported to exhibit enhanced sintering behavior under microwave radiation 
A

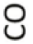

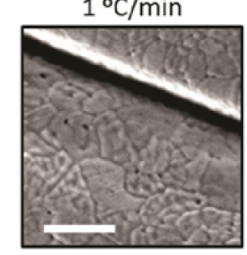

$5^{\circ} \mathrm{C} / \mathrm{min}$
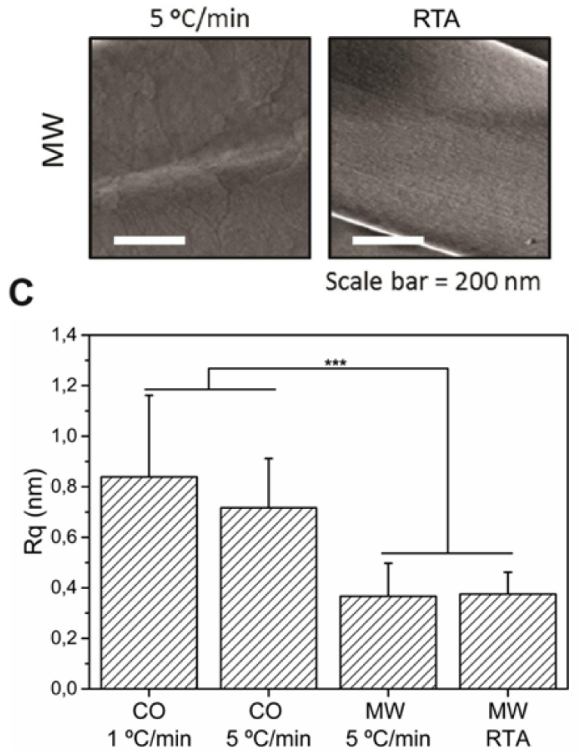

B

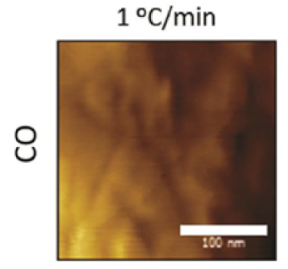

$5^{\circ} \mathrm{C} / \mathrm{min}$

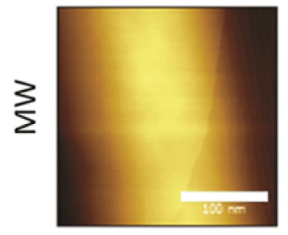

D

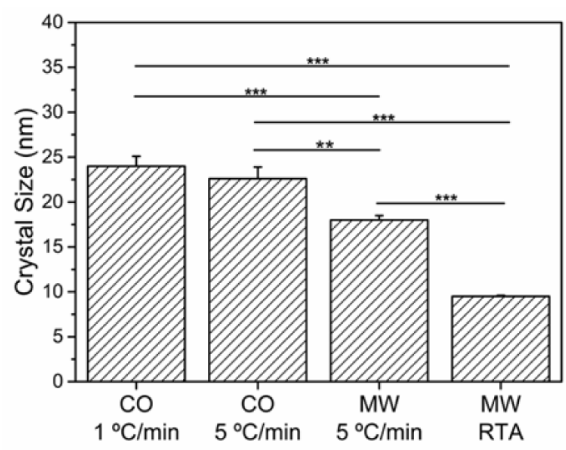

$5^{\circ} \mathrm{C} / \mathrm{min}$

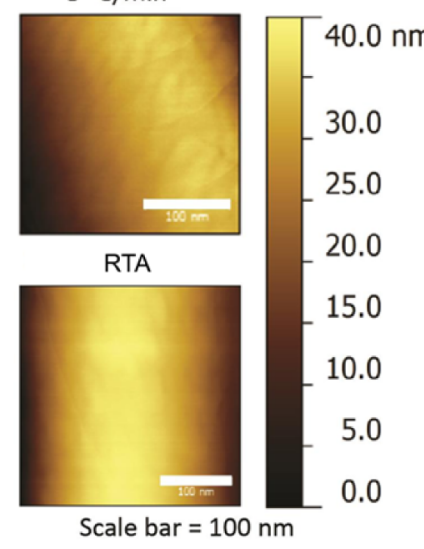

30.0

5.0

10.0

Figure 3. Effect of annealing procedure on the fiber surface morphology. (A) SEM images of YSZ nanofibers; the scale bar is $200 \mathrm{~nm}$. (B) AFM images of YSZ nanofibers; the scale bar is $100 \mathrm{~nm}$. (C) Roughness data extracted from AFM scans. (D) Grain sizes of the fibers calculated from the fwhm of the (111) peak of the XRD patterns. Error bars represent standard deviation of the mean. The statistical significance was determined using a one way ANOVA test, where $* * p<0.01$ and $* * * p<0.001$.

heating. ${ }^{32,33}$ Xie et al. reported smaller and more uniform grain sizes when YSZ was sintered in a MW, which is in accordance with our data (Figure 3D). ${ }^{33}$ The YSZ nanofibers presented here have a different surface nanostructure than any previously reported YSZ topography. They are nearly one-dimensional objects in a porous matrix, which affects the heat transport and crystallization rates. Nevertheless, the smoothening of the surface, when annealed using a MW, can be attributed to a stepbunching effect (i.e., aggregation of the ceramic steps), ${ }^{34}$ sudden shrinkage and densification, ${ }^{32}$ and/or improved oxygen transport. $^{35}$

To elucidate the performance of our nanofibrillar YSZ in bone tissue regeneration, hMSCs were grown on samples annealed at $5{ }^{\circ} \mathrm{C} / \mathrm{min}$ using both $\mathrm{CO}$ and $\mathrm{MW}$ heating. We chose these samples as they have the same temperature profile during annealing, grain sizes in the same order of magnitude, and similar fiber diameter distributions, yet different surface roughness. Recent studies revealed the importance of nanoscale and submicron-sized topographic cues to modulate fundamental cell behavior, including proliferation, migration, and differentiation. $^{36-38}$ We hypothesized, therefore, that the nanofibrous structure and the different surface roughness of YSZ scaffolds may confer bioactive cues to an otherwise biologically inert ceramic material. Such topographical cues would ultimately result in varying cell morphology and, consequently, in different cell activities. The bioactivity of hMSCs on ceramic scaffolds was investigated by monitoring the cell viability, cellular morphology, cellular metabolism, alkaline phosphatase (ALP) activity, and gene expression in basic culture medium $(\mathrm{BM})$ and osteogenic culture medium $(\mathrm{OM})$ at days 7 and 14. Polystyrene tissue culture plates were used as a positive control (data not shown). The production of mineralized matrix was investigated after culturing cell-scaffold constructs in mineralization culture medium (MM) up to 28 days. Here, different culture media were chosen to investigate the influence of YSZ scaffolds on the osteogenesis potential of hMSCs in the presence or absence of osteoinducting soluble factors. BM is a maintenance medium that does not trigger the osteogenic differentiation of hMSCs. ${ }^{39,40}$ On the other hand, $\mathrm{OM}$ induces osteogenic differentiation of hMSCs, whereas MM supports osteogenic differentiation and promotes the formation of mineralized matrix. ${ }^{39,41}$

To evaluate the viability of hMSCs on YSZ nanofibrillar scaffolds, a live/dead assay was performed after 3 days of culture. The fluorescence microscopy images of both live and dead cells on scaffolds are shown in Figure S4. All investigated scaffolds showed a high rate of viable cells, which indicates no cytotoxic effects derived from the developed YSZ nanofibrillar scaffolds.

The cell morphology on YSZ scaffolds was investigated by SEM (Figure 4A-C). The cell cytoskeleton was further assessed by staining with phalloidin for actin filaments (Figure $4 \mathrm{D}-\mathrm{F}$ ), and the average surface area for single cell was quantified (Figure 4G). Cells on CO annealed scaffolds had a higher cell area compared to MW annealed scaffolds, which could be correlated to the difference in surface roughness of the nanofibers. When comparing to bulk YSZ (having a roughness of $19 \pm 0.94 \mathrm{~nm}$ which is typical for a smooth bulk ceramic surface), no significant difference in the average cell area was found, possibly due to the combined effect of surface roughness 

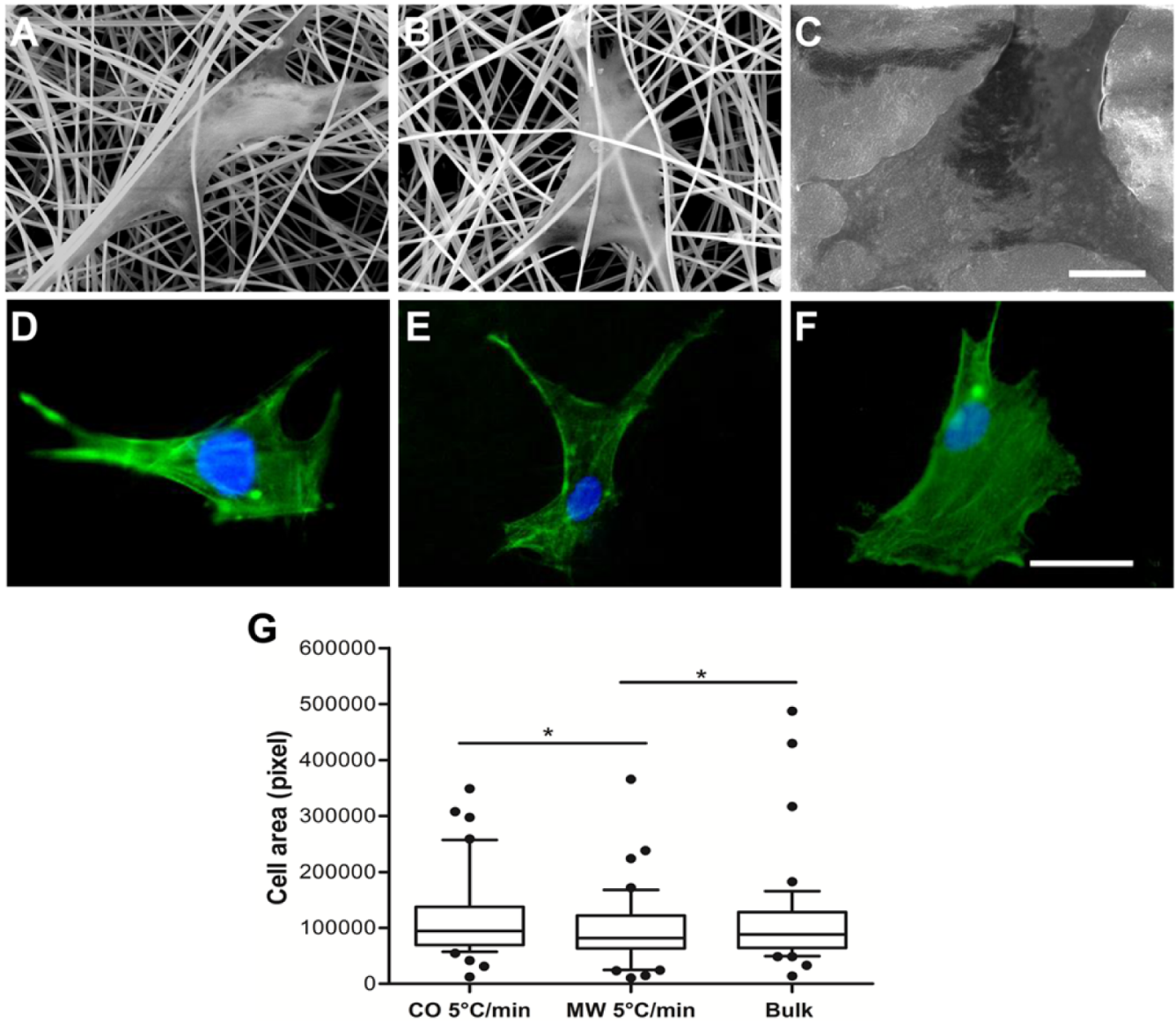

Figure 4. Characterization of cell morphology and actin cytoskeleton organization of hMSCs after 3 days of culture in BM. Representative SEM images of hMSCs on (A) microwave annealed (MW $5{ }^{\circ} \mathrm{C} / \mathrm{min}$ ) nanofiber scaffolds, (B) conventional oven annealed $\left(\mathrm{CO} 5{ }^{\circ} \mathrm{C} / \mathrm{min}\right)$ nanofiber scaffolds, and (C) YSZ bulk disk scaffolds. Representative images of actin cytoskeleton organization of hMSCs on (D) microwave annealed (MW $5{ }^{\circ} \mathrm{C} / \mathrm{min}$ ) scaffolds, (E) conventional oven annealed $\left(\mathrm{CO} 5{ }^{\circ} \mathrm{C} / \mathrm{min}\right.$ ) scaffolds, and (F) YSZ bulk disk scaffolds (actin filaments labeled with phalloidin are shown in green and nuclei labeled with DAPI are shown in blue). (G) Quantification of projected cell area on the investigated scaffolds. The statistical analysis was determined using two-tailed Student's $t$ test, and $* p<0.05$ was considered as significant difference. The scale bars in $(\mathrm{A}-\mathrm{C})$ and $(\mathrm{D}-\mathrm{F})$ are 10 and $50 \mu \mathrm{m}$, respectively.

and nanoscale fibrous structure. It is worthy to mention that the difference in surface roughness between YSZ nanofibers and bulk YSZ illustrates that the outer dimensions of fibers and bulk material differ and also their surface morphologies.

Cell metabolic activity, which is indirectly related to cell viability, was determined using a PrestoBlue assay. The metabolic activity of hMSCs showed a similar profile in BM and OM (Figure S5). Bulk YSZ scaffolds had a significantly higher metabolic activity than all nanofibrous scaffolds, which could be due to the higher differentiation of hMSCs on nanofibrous scaffolds compared to bulk YSZ. Similar phenomena have been reported previously by Yuejun and his colleagues. $^{42}$ They found that hMSCs had higher metabolic activity on stiffer PDMS than the soft one, while a higher differentiation activity of hMSCs was observed on soft PDMS compared to a stiffer one. In addition, no significantly different metabolic activity was observed between $\mathrm{CO}$ and $\mathrm{MW}$ annealed scaffolds. This indicates that the surface roughness differences did not affect the cellular metabolism in the present work.

Polymerase chain reaction (PCR) was used to quantify the expression of a panel of osteogenic genes (Figures 5C and S6). Gene expression of Runt-related transcription factor 2 (RUNX2) was significantly higher for $\mathrm{CO}$ and MW annealed scaffolds compared to bulk YSZ in both culture media. RUNX2 is considered as a focal point for integration of a variety of signals affecting the differentiation process of hMSCs into osteogenesis in the early stage, because it stimulates other downstream osteo-related genes such as osteopontin (OPN), osteocalcin (OCN), bone sialoprotein (BSP), and type I collagen. ${ }^{43}$ Collagen type I alpha 1 (COL1A1) is fundamental for the development of the bone cell phenotype. It is actively expressed in the first proliferation period and then gradually down-regulated during subsequent osteoblast differentiation. ${ }^{44}$ hMSCs cultured on annealed nanofibrous scaffolds showed higher expression of COL1A1 compared to bulk YSZ disks in both culture media. This is also associated with a significantly higher up-regulation of OCN and BSP on the nanofibrillar scaffolds in BM compared with bulk YSZ disks (Figure S6). Furthermore, the rougher meshes supported further enhanced OCN and BSP gene expression than the smoother ones, thus suggesting the possible role of surface topography on inducing hMSCs osteogenic differentiation, as also supported by other studies. $^{45,46}$ OPN was only significantly up-regulated on nanofibrillar scaffolds at day 7 in OM, while no beneficial effect of surface topography or nanofibrillar cues was observed for OCN or BSP in OM both at day 7 and at day 14. Since one of the routes for hMSCs differentiation toward the osteogenic lineage passes through endochondral development, ${ }^{47,48}$ the 
A

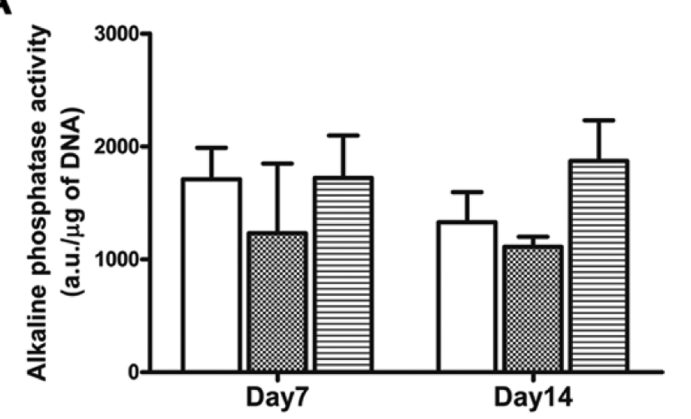

B

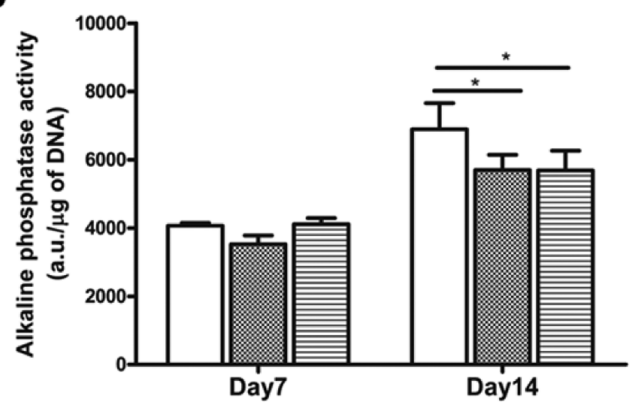

C
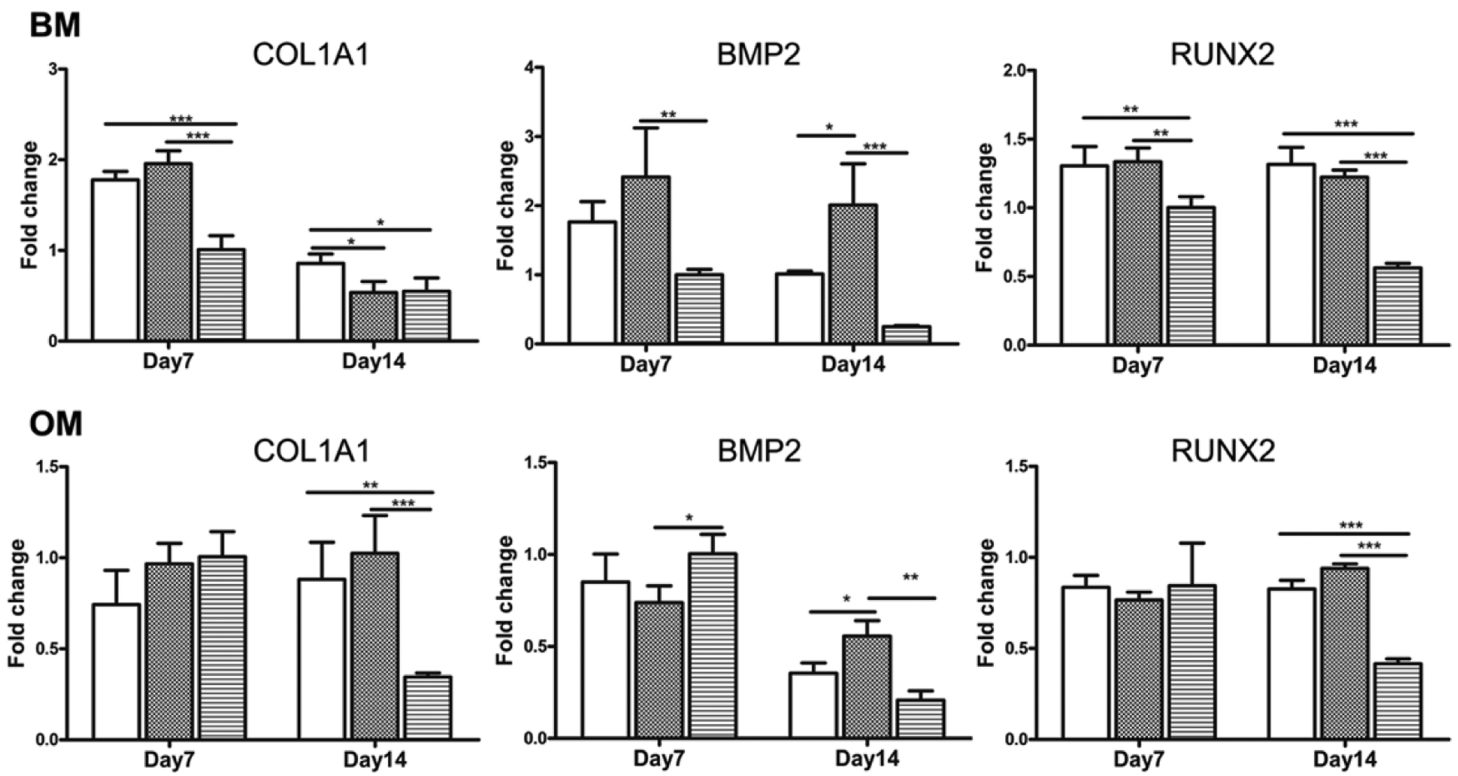

$\mathrm{CO} 5^{\circ} \mathrm{C} / \mathrm{min}$

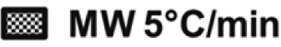

Bulk

Figure 5. (A and B) ALP activity and (C) gene expression analysis from hMSCs cultured on conventional oven annealed (CO $\left.5{ }^{\circ} \mathrm{C} / \mathrm{min}\right)$, microwave annealed (MW $5{ }^{\circ} \mathrm{C} / \mathrm{min}$ ), and YSZ bulk disk scaffolds. ALP activity of hMSCs cultured in (A) BM and (B) OM at days 7 and 14 (the final ALP activity level was shown after normalizing to DNA amount). (C) Gene expression analysis for COL1A1, BMP2, and RUNX2 at days 7 and 14 in BM and OM (the final gene expression level was presented after normalizing to day 7 bulk YSZ). Error bars represent standard deviation of the mean. $* p<0.05, * * p<0.01, * * * p<0.001$.

down-regulation of OCN and BSP on nanofibrous scaffolds in comparison with their bulk disks could be also attributed to a higher hypertrophic differentiation of hMSCs, and therefore a less mature osteogenic differentiation, on bulk disks due to their smooth surface properties in combination of medium stimuli. The smooth surface properties will affect the cell-to-material adhesion force and could have consequently influenced cell fate as well. ${ }^{49}$ We also observed the expression of bone morphogenetic protein 2 (BMP2), which is known to be stimulating hMSCs along the osteogenic lineage. ${ }^{50} \mathrm{BMP} 2$ had a higher expression in all tested media on both nanofibrillar scaffolds compared to bulk YSZ except for day 7 in OM. Altogether, the ceramic nanofibrous scaffolds supported the osteogenic gene expression in both $\mathrm{BM}$ and $\mathrm{OM}$, thus suggesting a possible role of the nanofibrillar cues inherently built in the YSZ meshes in contributing to hMSCs osteogenic differentiation. In addition, the varying surface roughness resulting from the different fiber annealing processes showed a net beneficial effect in the case of OCN and BSP genes, which occurred only for the rougher nanofibrous scaffolds obtained by employing conventional heating. It is also worth mentioning that there were different trends in OM compared to BM, which might suggest that the differentiation of hMSCs in the present study was not only due to surface roughness but also to other physical stimuli cues such as surface topography, porosity, and physical cues associated with the nanoscale nature of the fibrillar meshes. Further studies should aim at clarifying the specific role of each of these material properties on cell differentiation and the consequent osteoinductive nature of such nanofibrillar scaffolds, in addition to the osteoconductive properties here observed, both in vitro and in vivo.

At a protein level, the up-regulation of ALP activity is a common marker considered for the early stage of osteogenesis. ${ }^{43}$ In BM, no significant differences were observed in ALP activity (Figure 5A). On the other hand, the ALP activity increased between day 7 and day 14 in $O M$ and was significantly enhanced for $\mathrm{CO}$ annealed scaffolds compared to both MW annealed scaffolds and bulk YSZ (Figure 5B). These results indicate that the topographical properties of nanofibers, including larger surface area, higher porosity, and fibrous morphology, play a positive role in the osteogenic process of hMSCs. Similar results to our findings have been reported by 
A
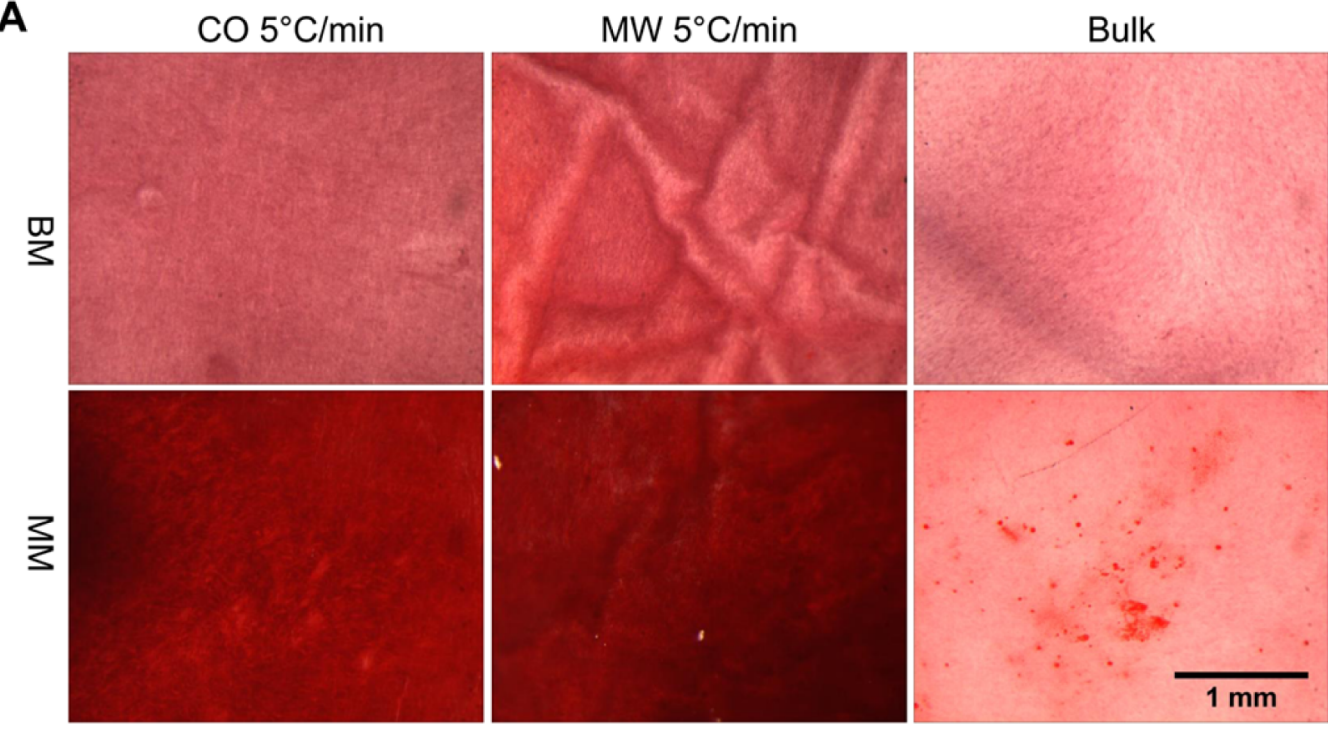

B

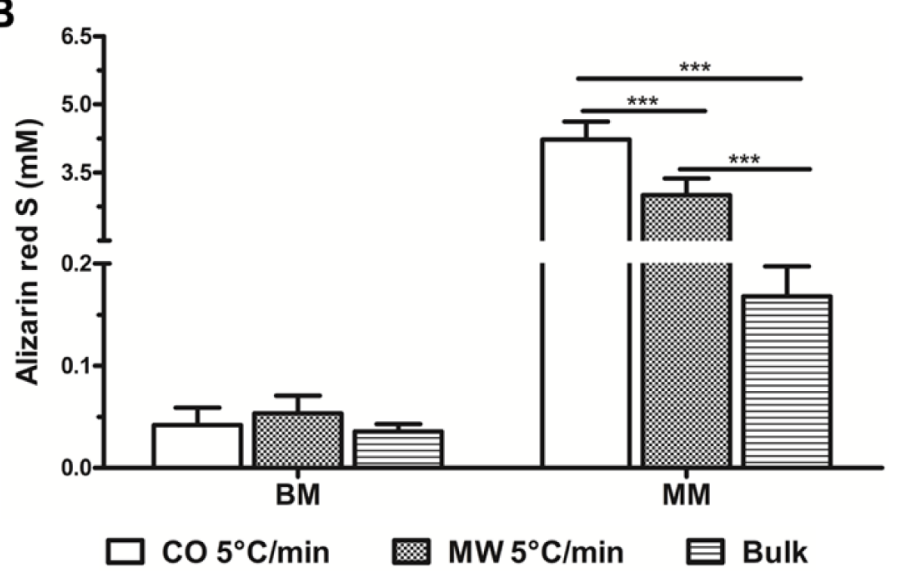

Figure 6. Calcium mineralization on conventional oven annealed $\left(\mathrm{CO} 5{ }^{\circ} \mathrm{C} / \mathrm{min}\right)$, microwave annealed $\left(\mathrm{MW} 5{ }^{\circ} \mathrm{C} / \mathrm{min}\right)$, and YSZ bulk disk scaffolds. (A) The formation of mineralized extracellular matrix was stained with alizarin red $S$ after 28 days of culture in BM and MM (the scale bar represents $1 \mathrm{~mm}$ ). (B) Quantitative analysis of the mineral deposits per scaffold by alizarin red $S$ staining at day 28 . Error bars represent standard deviation of the mean. ${ }^{* * *} p<0.001$.

Hae-Won Kim and colleagues $^{51}$ who used bone marrowderived stem cells to investigate the osteogenic potential of newly developed glass fibers. Their results demonstrated that bioactive glass nanofibers showed a stronger ALP staining with respect to glass disks.

The ultimate deposition of a calcium-containing bone-like mineralized matrix is an index of extended osteogenic maturation of hMSCs. Mineralization was stained with alizarin red S after 28 days of culture (Figures 6 and S7). When hMSCs were cultured on scaffolds in BM, little mineralized ECM was produced, and no apparent differences were observed among the different scaffolds. In MM, a robust mineralized matrix was observed on bulk YSZ discs, while a strikingly significant increase in the amount of mineralized matrix was observed on the nanofibrous scaffolds. Quantification of the calcium deposits corroborated the staining results, showing significantly enhanced calcium deposition on both fiber scaffolds compared to the bulk YSZ discs (Figure 6B). Here, the rougher CO annealed scaffolds resulted in a further enhancement of calcium content compared to the MW annealed scaffolds. This result is similar to the finding by Takeuchi and his co-workers, who demonstrated that osteoblasts show a higher rate of matrix mineralization on rougher titanium surfaces. ${ }^{52}$ A recent study showed that hMSCs cultured on calcium phosphate cements had a mineral concentration of about $1 \mathrm{mM}$ per scaffold at day $21{ }^{53}$ Compared to this study, our nanofibers annealed in a conventional oven had almost 3 -fold higher mineral concentration. However, when comparing to other studies, care should be taken as different cell donors, time point, and cell seeding density have been used.

\section{CONCLUSIONS}

In summary, new flexible nanofibrous YSZ scaffolds that display multiscale mechanical properties were successfully fabricated by electrospinning. Their surface roughness can be tailored by employing different heat treatment methods. Our results demonstrate that the osteogenic differentiation and mineralization of seeded human mesenchymal stromal cells were supported by the nanofibrous structure of YSZ scaffolds, in contrast to the well-known bioinert behavior of bulk YSZ. These flexible scaffolds can therefore present an appealing alternative to current brittle ceramics for bone regeneration applications. 


\section{EXPERIMENTAL PROCEDURES}

Electrospinning. Zirconium $n$-propoxide (Alfa Aesar, Lancashire, U.K.) and yttrium acetate hexahydrate (Alfa Aesar, Lancashire, U.K.) were dissolved in $n$-propanol (Sigma-Aldrich) in a 97:3\% molar ratio. Then, polyvinylpyrrolidone (PVP) $\left(M_{\mathrm{W}} 1.3 \mathrm{~kg} / \mathrm{mol}\right.$, Sigma-Aldrich, St. Louis, U.S.A.) was added to the solution and left stirring overnight to ensure complete dissolution of the PVP. The solution preparation was performed in a nitrogen atmosphere. Subsequently, the solution was placed into a syringe, which was later connected to Teflon tubing with a $0.8 \mathrm{~mm}$ needle and placed in the needle holder of the electrospinning setup. The flow rate was set at $1 \mathrm{~mL} / \mathrm{h}$, the air gap was $20 \mathrm{~cm}$, the voltage was $15 \mathrm{kV}$, and the temperature and the relative humidity were set to $25{ }^{\circ} \mathrm{C}$ and $30 \%$, respectively.

Thermal Annealing. The YSZ-PVP fibers were annealed to burn out the organic phase and to obtain a pure YSZ crystalline phase. The samples were annealed either in a CO (Carbolite, Hope Valley, U.K.) or a MW (Milestone MicroSynth, Shelton, U.S.A.) at different heating rates. The samples annealed in the $\mathrm{CO}$ were heated at 1 and $5{ }^{\circ} \mathrm{C} / \mathrm{min}$ to $850{ }^{\circ} \mathrm{C}$. The samples annealed in the MW were either heated at 5 ${ }^{\circ} \mathrm{C} / \mathrm{min}$ to $850{ }^{\circ} \mathrm{C}$ or by RTA. RTA consisted on placing the sample directly in a preheated $\mathrm{MW}$ at $850^{\circ} \mathrm{C}$, and after annealing the samples were cooled to room temperature (rt) without a temperature program.

Fiber Morphology and Diameter. The fiber morphology was studied by a Zeiss Merlin (Oberkochen, Germany) scanning electron microscope at high magnification. The fiber diameter was determined from low-magnification SEM pictures. The imaging was done at 1.4 $\mathrm{keV}$. Fifty measurements were performed per micrograph and per sample, respectively.

Phase Identification and Crystallite Size. The crystallinity and phase purity of the samples were studied by X-ray diffraction in the $2 \theta$ range between $10^{\circ}$ and $100^{\circ}$ using a PANAlytical X'Pert (Almelo, The Netherlands), with a step size of $0.015^{\circ}$ and $8 \mathrm{~s}$ per step. The crystallite size was estimated using the Scherrer equation from the fwhm of the (111) peak. The Scherrer equation is presented in eq 1 :

$$
\tau=\frac{K \lambda}{\beta \cos \theta}
$$

where $\tau$ is the crystallite size, $K$ is the dimensionless shape factor, $\lambda$ is the X-ray wavelength, $\beta$ is the fwhm of the peak, and $\theta$ is the Bragg's diffraction angle.

Macroscopic Mechanical Properties. The mechanical properties of the ceramic nanofiber mats $(n=3)$ were measured by means of microindentation. A Piuma microindenter (Optics 11, Amsterdam, The Netherlands) equipped with a tip with a radius of $37.5 \mu \mathrm{m}$ and a spring constant of $199 \mathrm{~N} / \mathrm{m}$ was utilized. Twenty-five points were scanned throughout $2500 \mu \mathrm{m}^{2}$ for each sample.

Microscopic Mechanical Properties and Surface Morphology. The microscopic mechanical properties were measured by a three-point bending test on a single nanofiber, as previously reported elsewhere. ${ }^{30,31}$ A polycarbonate substrate with $90 \mu \mathrm{m}$ wide channels was used as a substrate to suspend the fibers. An atomic force microscope (Bruker Icon, Massachusetts, U.S.A.) equipped with a ScanAsyst-AIR (Bruker, Massachusetts, U.S.A.) tip was used to measure the force/displacement curves of the fiber. The tip had a spring constant of $0.4 \mathrm{~N} / \mathrm{m}$ and a resonance frequency of $70 \mathrm{kHz}$. The apparent Young's modulus was calculated with the Euler/Bernulli beam theory (eq 2) using the average fiber diameter obtained from SEM:

$$
E^{*}=\left(\frac{F}{d}\right) \frac{L^{3}}{12 \pi r D^{4}}
$$

Here $E^{*}$ is the apparent Young's modulus, $F / d$ is the slope of the force displacement curve, $L$ is the gap distance, and $D$ is the fiber diameter. The fiber surfaces were also scanned using the same tip in tapping mode to obtain surface morphology data. The roughness values (Rq) were obtained by analyzing the AFM topography data using the Gwyddion software package (version 2.31).

Fatigue Test. A three-point bending fatigue test was performed on the ceramic nanofiber mats $(n=3)$. This version of the three-point bending test was especially designed for the experiment and consisted of (1) a plate with a well-defined gap, on which the sample was suspended on, and (2) a knife, which applied a force to deflect the sample. The gap was $2 \mathrm{~mm}$ wide, and the knife was $0.5 \mathrm{~mm}$ thick. The width of the sample was kept constant at $10 \mathrm{~mm}$. The plate and knife were set on a rheometer (Anton Paar Physica MCR 501, Graz, Austria), which measured the force displacement curves at a speed of $50 \mu \mathrm{m} / \mathrm{s}$.

The sample's deflection was calculated assuming a trigonometric system between the sample, knife, and gap. Thus, if the displacement of the knife is known, the deflection angle may be calculated using half of the gap distance. This is exemplified in Figure S8.

Cell Culture. Preselected hMSCs (donor no. 8001L) were isolated from human bone marrow by the Institute of Regenerative Medicine (Texas A\&M University, Temple, Texas), which provide standardized preparations of MSCs for research use under the auspices of an NIH/ NCRR grant (P40 RR 17447-06). ${ }^{54,55}$ Briefly, mononuclear cells were separated using density centrifugation and plated to obtain adherent hMSCs. The cells were harvested around a confluence of $60-80 \%$, after which they were considered as passage zero (P0). The P0 cells were further expanded and harvested to obtain passage 1 (P1). To obtain sufficient cells for scaffold-based experiments, hMSCs (P1) were expanded in T-300 flasks at a density of $3 \times 10^{5} \mathrm{cells} / \mathrm{cm}^{2}$ and cultured in BM, consisting of $\alpha$-MEM (Gibco), $10 \%$ fetal bovine serum (Lonza), $2 \mathrm{mM}$ L-glutamine (Gibco), $0.2 \mathrm{mM}$ ascorbic acid (Sigma), $100 \mathrm{U} / \mathrm{mL}$ penicillin, and $100 \mathrm{mg} / \mathrm{mL}$ streptomycin (Gibco). The cells were harvested at approximately $80-90 \%$ confluence for further subcultures.

Cell Seeding on Scaffolds. The ceramic scaffolds were cleaned using oxygen plasma cleaning (Harrick Plasma PDC-002) for $10 \mathrm{~min}$ at high power and subsequently punched out into discs to fit inside a 24-well plate. Rubber O-rings (Eriks B.V., The Netherlands) were inserted into the well to hold the substrate on the bottom. The ceramic scaffolds were sterilized in $70 \%(\mathrm{v} / \mathrm{v})$ ethanol for $15 \mathrm{~min}$ each time for 3 times. After sterilization, the scaffolds were rinsed with PBS for 5 min each time for 3 times and immersed in $\mathrm{BM}$ at $37{ }^{\circ} \mathrm{C}$ overnight before cell seeding. Ceramic scaffolds were seeded at a density of $2 \times 10^{4}$ cells $/ \mathrm{cm}^{2}$ and cultured in an incubator with $5 \% \mathrm{CO}_{2}$ humid atmosphere at $37^{\circ} \mathrm{C}$ for up to 14 days in $\mathrm{OM}$ and in both BM and MM for 28 days. BM is considered a normal growth medium, which cannot induce osteogenic differentiation nor form a mineralized matrix. $^{39,41} \mathrm{OM}$ consisted of $\mathrm{BM}$ supplemented with $10^{-8} \mathrm{M}$ dexamethasone to induce osteogenic differentiation of hMSCs, and the MM consisted of OM supplemented with $\beta$-glycerophosphate to support the osteogenic differentiation ${ }^{39,41}$ and promote the formation of a mineralized matrix. The culture medium was refreshed every 2 days.

Live and Dead Assay. To determine the cell viability on scaffolds, a live/dead assay (Life Technologies) was performed. After washing the scaffolds twice with PBS, they were incubated for $30 \mathrm{~min}$ with a mixture of PBS solution containing ethidium homodimer (red fluorescent)/calcein AM (green fluorescent) at rt following the manufacturer's protocol. Scaffolds were washed three times with PBS before imaging with a fluorescence microscope (Nikon, Eclipse E600 and Nikon DS-Filc camera).

SEM Analysis. After 3 days of culture, the medium was removed, and the scaffolds were washed two times with PBS and fixed in a $10 \%$ formalin solution for $2 \mathrm{~h}$. After rinsing with PBS, the scaffolds were dehydrated with ethanol series $(50 \%, 70 \%, 80 \%, 90 \%, 96 \%$, and $100 \%)$. The scaffolds were further processed by critical point drying (Balzers CPD-030). The dried samples were sputtered with gold (Cressington) and imaged with a XL-30 ESEM-FEG SEM (FEI, Eindhoven, Netherlands).

Fluorescence Microscopy. At day 3, samples for phalloidin staining were fixed with $4 \%(\mathrm{v} / \mathrm{v})$ paraformaldehyde (Sigma-Aldrich) in PBS, left overnight at $4{ }^{\circ} \mathrm{C}$, and subsequently washed 3 times with PBS. Afterward, the cell membrane was permeabilized with $0.5 \%$ TritonX-100 solution for $10 \mathrm{~min}$ at $4{ }^{\circ} \mathrm{C}$ and washed with PBS again. A $1 \%$ BSA in PBS solution was added for $2 \mathrm{~h}$ to block nonspecific binding. After withdrawing the BSA solution, phalloidin (Alexa Fluor 
Table 1. Sequences of Primers Used in PCR

\begin{tabular}{ll}
\multicolumn{1}{c}{ gene } & \multicolumn{1}{c}{ forward primer $5^{\prime}$ to $3^{\prime}$} \\
BMP-2 & ACTACCAGAAACGAGTGGGAA \\
BSP & CCCCACCTTTTGGGAAAACCA \\
OPN & CTCCATTGACTCGAACGACTC \\
OCN & TGAGAGCCCTCACACTCCTC \\
ALP & ACAAGCACTCCCACTTCATC \\
RUNX2 & TGGTTACTGTCATGGCGGGTA \\
COL1A1 & GAGGGCCAAGACGAAGACATC \\
B2M & ACAAAGTCACATGGTTCACA
\end{tabular}

$\quad$ reverse primer $5^{\prime}$ to $3^{\prime}$
GCATCTGTTCTCGGAAAACCT
TCCCCGTTCTCACTTTCATAGAT
CAGGTCTGCGAAACTTCTTAGAT
CGCCTGGGTCTCTTCACTAC
TTCAGCTCGTACTGCATGTC
TCTCAGATCGTTGAACCTTGCTA
CAGATCACGTCATCGCACAAC
GACTTGTCTTTCAGCAAGGA

488, Invitrogen; excitation/emission: 495/518 nm) with a dilution $(1: 40)$ in $1 \% \mathrm{BSA} / \mathrm{PBS}$ was applied for $25 \mathrm{~min}$ at $\mathrm{rt}$ in the dark and rinsed 3 times with PBS. For nuclei staining, DAPI $(1: 100)$ in PBS was applied for $15 \mathrm{~min}$ at $\mathrm{rt}$ in the dark. The samples were observed under a fluorescence microscope (Eclipse E600, Nikon) equipped with proper filter. The average surface area for single cells was determined by the software CellProfiler 2.1.1 (Broad Institute, Cambridge, U.S.A.). The surface area in each of at least 10 cells within an image for a total of six images per sample were quantified. All these images were from the same experiment.

Cell Metabolic Activity. The cell metabolic activities on days 7 and 14 were assessed using a PrestoBlue Cell Viability Reagent (Life technologies), according to the manufacturer's protocol. Briefly, a cultured medium was replaced with a medium containing $10 \%(\mathrm{v} / \mathrm{v})$ PrestoBlue reagent, and cells were incubated for $1 \mathrm{~h}$ at $37^{\circ} \mathrm{C}$. Fluorescence was measured at $590 \mathrm{~nm}$ on a PerkinElmer Victor3 1420 multiple plate reader. Three separate experiments $(n=3)$ and two replicates each were performed.

ALP Activity. The relative ALP activity was measured by chemoluminescence with a CDP-star kit (Roche Life Science), according to the manufacturer's instruction. Briefly, cell-scaffold constructs were washed 3 times with PBS and stored at $-80{ }^{\circ} \mathrm{C}$ for at least $24 \mathrm{~h}$. After thawing, the constructs were treated with $250 \mu \mathrm{L}$ cell lysis buffer at a $\mathrm{pH}$ of 7.8 (composed of $0.1 \mathrm{M} \mathrm{KH}_{2} \mathrm{OPO}_{4}, 0.1 \mathrm{M}$ $\mathrm{K}_{2} \mathrm{HPO}_{4}$, and $0.1 \%$ Triton X-100) for $1 \mathrm{~h}$ at rt. Cell lysates $(50 \mu \mathrm{L})$ were transferred to Eppendorf tubes and stored at $-20{ }^{\circ} \mathrm{C}$ for ALP assay. The remainder of the remaining cell lysates $(200 \mu \mathrm{L})$ was used for DNA assay. For ALP analysis, $10 \mu \mathrm{L}$ of cell lysates were transferred in duplicate to a well of a 96-well plate. Subsequently, $40 \mu \mathrm{L}$ of CDPstar were added, and plates were incubated for $15 \mathrm{~min}$ at $\mathrm{rt}$. The plates were measured on a Multilabel reader (Victor3 1420, PerkinElmer, U.S.A.). Three separate experiments $(n=3)$ and two replicates each were performed. The results of ALP activity were presented after normalization to DNA quantity per scaffold.

Quantification of DNA Amount. Cell lysates remainder, (200 $\mu \mathrm{L})$ as mentioned above, were further digested for $16 \mathrm{~h}$ at $56^{\circ} \mathrm{C}$ with $200 \mu \mathrm{L}$ Tris/EDTA buffer containing $1 \mathrm{mg} / \mathrm{mL}$ proteinase $\mathrm{K}$ (SigmaAldrich), $185 \mu \mathrm{g} / \mathrm{mL}$ iodoacetamine (Sigma-Aldrich), and $10 \mu \mathrm{g} / \mathrm{mL}$ Pepstatin A (Sigma-Aldrich). The quantification of the total amount of DNA was performed using the CyQuant DNA assay (Molecular Probes, Eugene, U.S.A.) according to the manufacturer's manual. Briefly, a $40 \mu \mathrm{L}$ aliquot of lysate was pipetted in duplicate into a black 96-well plate, followed by addition of $40 \mu \mathrm{L}$ RNase (1000×) in NaClEDTA buffer composed of component B $(20 \times)$ and incubated for $1 \mathrm{~h}$ at rt. Subsequently, $80 \mu \mathrm{L}$ of Gr-dye solution was added and incubated for $15 \mathrm{~min}$. The measurements were performed on a spectrophotometer reader (Victor3 1420, PerkinElmer, U.S.A.) at an excitation wavelength of $480 \mathrm{~nm}$ and an emission wavelength of $520 \mathrm{~nm}$. Three separate experiments $(n=3)$ and two replicates each were performed.

Gene Expression Analysis. Total RNA was isolated from samples at days 7 and 14 using a combination of TRIzol with a NucleoSpinRNAII isolation kit (Bioke). Briefly, the scaffolds were washed three times with PBS, and $1 \mathrm{~mL}$ of TRIzol was added for each sample. Then, $0.2 \mathrm{~mL}$ of chloroform was added, and the samples were centrifuged for $15 \mathrm{~min}$ at 12,000 RCF (relative centrifugal force). The aqueous phase containing RNA was transferred to a new Eppendorf tube, mixed with an equal volume of $75 \%(\mathrm{v} / \mathrm{v})$ ethanol, and loaded onto an RNA binding column of the isolation kit. After a series of purification procedures, the RNA was resuspended in RNASE-free water. RNA concentration and purity were measured by using an ND 1000 spectrophotometer (Nanodrop Technologies, U.S.A.). Finally, cDNA was synthesized using iScript (Bio-Rad, Veenendaal, The Netherlands) according to the manufacturer's protocol. Quantitative PCR was performed using SYBR-green supermix (Bio-Rad). Four separate experiments $(n=4)$ were performed. Cycling parameters for quantitative PCR were as follows: initial denaturation for $10 \mathrm{~min}$ at 95 ${ }^{\circ} \mathrm{C}$, followed by 40 cycles of $15 \mathrm{~s}$ at $95{ }^{\circ} \mathrm{C}$ and $1 \mathrm{~min}$ at $60{ }^{\circ} \mathrm{C}$. The sequences of the analyzed primers are shown in Table 1 . Cycle threshold (CT) values were normalized to the housekeeping gene $\mathrm{B}_{2} \mathrm{M}$, and the results of gene expression were calculated as $2^{-\Delta \mathrm{CT}}$.

Alizarin Red S Staining and Quantification. After 28 days of culture, samples were washed with PBS, fixed with $10 \%$ formalin for 1 $\mathrm{h}$, and then subsequently with PBS and twice with distilled water. A freshly filtered $2 \%$ aqueous alizarin red $\mathrm{S}$ solution ( $\mathrm{pH}$ 4.2) was applied to scaffolds for $2 \mathrm{~min}$, after which the excess solution was washed off with distilled water. The quantification of orange-red coloration of alizarin red $S$ was carried out as in previous studies. ${ }^{43,56}$ Briefly, constructs were transferred to a microcentrifuge tube before removing excess water. A $10 \%$ acetic acid solution was added, and samples were shaken for $30 \mathrm{~min}$ at $\mathrm{rt}$. After vortexing for $30 \mathrm{~s}$, the solution was centrifuged for $15 \mathrm{~min}$ at 20,000 RCF, and the supernatant phase was removed to a new $1.5 \mathrm{~mL}$ microcentrifuge tube. A $10 \%$ ammonium hydroxide solution was added dropwise to neutralize the acid. Aliquots of the supernatant phase were measured in triplicate at $405 \mathrm{~nm}$ in a 96-well plate using opaque-walled, transparent-bottomed plates (Fisher Lifesciences). Three separate experiments $(n=3)$ and two replicates each were performed. Scaffolds without seeding cells were used as control.

Statistics. All data points are expressed as mean values \pm standard deviation. Statistical analysis was carried out using GraphPad Prism 5.01 (GraphPad software, San Diego, U.S.A.) for windows. The statistical differences were determined by using two-way analysis of variance (ANOVA), followed by a Tukey's posthoc test unless otherwise mentioned. A value of $p<0.05$ was considered statistically significant.

\section{ASSOCIATED CONTENT}

\section{Supporting Information}

The Supporting Information is available free of charge on the ACS Publications website at DOI: 10.1021/acsnano.5b08005.

Flexibility and fire resistance of ceramic nanofibers (AVI) Single fiber deflected with the atomic force microscope tip (AVI)

Fiber diameter distribution, XRD patterns of the nanofiber mats, the average fiber diameter and Young's moduli, live and dead assay, metabolic activity assay, other osteogenic genes expression, the control for calcium deposition assay, schematic of three-point bending fatigue test (PDF) 


\section{AUTHOR INFORMATION}

\section{Corresponding Authors}

*E-mail: 1.moroni@maastrichtuniversity.nl.

*E-mail: j.e.tenelshof@utwente.nl.

\section{Author Contributions}

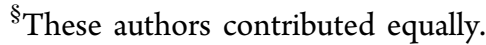

\section{Notes}

The authors declare no competing financial interest.

\section{ACKNOWLEDGMENTS}

H.C. thanks the China Council Scholarship programme for financial support (grant no. 2011614016). G.C.G. thanks the ADEM Programme for financial support. Roy Visser is thanked for assistance in mechanical testing, and Aliaksei Vasilevich for help in calculating the cell areas. Some of the materials employed in this work were provided by the Texas A\&M Health Science Center College of Medicine Institute for Regenerative Medicine at Scott \& White through a grant from NCRR of the NIH (grant no. P40RR017447).

\section{REFERENCES}

(1) Champion, E. Sintering of Calcium Phosphate Bioceramics. Acta Biomater. 2013, 9, 5855-5875.

(2) Best, S. M.; Porter, A. E.; Thian, E. S.; Huang, J. Bioceramics: Past, Present and for the Future. J. Eur. Ceram. Soc. 2008, 28, 13191327.

(3) Zakaria, S. M.; Sharif Zein, S. H.; Othman, M. R.; Yang, F.; Jansen, J. A. Nanophase Hydroxyapatite as a Biomaterial in Advanced Hard Tissue Engineering: A Review. Tissue Eng., Part B 2013, 19, 431-441.

(4) Woodard, J. R.; Hilldore, A. J.; Lan, S. K.; Park, C. J.; Morgan, A. W.; Eurell, J. A. C.; Clark, S. G.; Wheeler, M. B.; Jamison, R. D.; Wagoner Johnson, A. J. The Mechanical Properties and Osteoconductivity of Hydroxyapatite Bone Scaffolds with Multi-Scale Porosity. Biomaterials 2007, 28, 45-54.

(5) Hutmacher, D. W. Scaffolds in Tissue Engineering Bone and Cartilage. Biomaterials 2000, 21, 2529-2543.

(6) Kim, H.-W.; Knowles, J. C.; Kim, H.-E. Hydroxyapatite/Poly $(\varepsilon$ caprolactone) Composite Coatings on Hydroxyapatite Porous Bone Scaffold for Drug Delivery. Biomaterials 2004, 25, 1279-1287.

(7) Karageorgiou, V.; Kaplan, D. Porosity of 3D Biomaterial Scaffolds and Osteogenesis. Biomaterials 2005, 26, 5474-5491.

(8) Hutmacher, D. W.; Schantz, T.; Zein, I.; Ng, K. W.; Teoh, S. H.; Tan, K. C. Mechanical Properties and Cell Cultural Response of Polycaprolactone Scaffolds Designed and Fabricated via Fused Deposition Modeling. J. Biomed. Mater. Res. 2001, 55, 203-216.

(9) Piconi, C.; Maccauro, G. Zirconia As A Ceramic Biomaterial. Biomaterials 1999, 20, 1-25.

(10) Denry, I.; Kelly, J. R. State of The Art of Zirconia for Dental Applications. Dent. Mater. 2008, 24, 299-307.

(11) Hing, K. A.; Annaz, B.; Saeed, S.; Revell, P. A.; Buckland, T. Microporosity Enhances Bioactivity of Synthetic Bone Graft Substitutes. J. Mater. Sci.: Mater. Med. 2005, 16, 467-475.

(12) Meza, L. R.; Das, S.; Greer, J. R. Strong, Lightweight, and Recoverable Three-Dimensional Ceramic Nanolattices. Science 2014, 345, 1322-1326.

(13) Park, S.-J.; Chase, G.; Jeong, K.-U.; Kim, H. Mechanical Properties of Titania Nanofiber Mats Fabricated by Electrospinning of Sol-Gel Precursor. J. Sol-Gel Sci. Technol. 2010, 54, 188-194.

(14) Guo, M.; Ding, B.; Li, X.; Wang, X.; Yu, J.; Wang, M. Amphiphobic Nanofibrous Silica Mats with Flexible and High-HeatResistant Properties. J. Phys. Chem. C 2010, 114, 916-921.

(15) Biswas, A.; Park, H.; Sigmund, W. M. Flexible Ceramic Nanofibermat Electrospun from $\mathrm{TiO} 2-\mathrm{SiO} 2$ Aqueous Sol. Ceram. Int. 2012, 38, 883-886.
(16) Xi, M.; Wang, X.; Zhao, Y.; Feng, Q.; Zheng, F.; Zhu, Z.; Fong, $\mathrm{H}$. Mechanically Flexible Hybrid Mat Consisting of $\mathrm{TiO} 2$ and $\mathrm{SiO} 2$ Nanofibers Electrospun via Dual Spinnerets for Photo-Detector. Mater. Lett. 2014, 120, 219-223.

(17) Si, Y.; Tang, X.; Ge, J.; Yang, S.; El-Newehy, M.; Al-Deyab, S. S.; Yu, J.; Ding, B. In situ Synthesis of Flexible Magnetic $\gamma$-Fe2O3@SiO2 Nanofibrous Membranes. Nanoscale 2014, 6, 2102-2105.

(18) Chen, Y.; Mao, X.; Shan, H.; Yang, J.; Wang, H.; Chen, S.; Tian, F.; Yu, J.; Ding, B. Free-Standing Zirconia Nanofibrous Membranes with Robust Flexibility for Corrosive Liquid Filtration. RSC Adv. 2014, 4, 2756-2763.

(19) Mao, X.; Si, Y.; Chen, Y.; Yang, L.; Zhao, F.; Ding, B.; Yu, J. Silica Nanofibrous Membranes with Robust Flexibility and Thermal Stability for High-Efficiency Fine Particulate Filtration. RSC Adv. 2012, $2,12216-12223$

(20) Wang, R.; Guo, J.; Chen, D.; Miao, Y.-E.; Pan, J.; Tjiu, W. W.; Liu, T. "Tube Brush" like $\mathrm{ZnO} / \mathrm{SiO} 2$ Hybrid to Construct a Flexible Membrane with Enhanced Photocatalytic Properties and Recycling Ability. J. Mater. Chem. 2011, 21, 19375-19380.

(21) Chen, H.; Huang, J.; Yu, J.; Liu, S.; Gu, P. Electrospun Chitosan-Graft-Poly ( $\varepsilon$-caprolactone)/Poly ( $\varepsilon$-caprolactone) Cationic Nanofibrous Mats As Potential Scaffolds for Skin Tissue Engineering. Int. J. Biol. Macromol. 2011, 48, 13-19.

(22) Chen, H.; Fan, X.; Xia, J.; Chen, P.; Zhou, X.; Huang, J.; Yu, J.; $\mathrm{Gu}, \mathrm{P}$. Electrospun Chitosan-Graft-Poly ( $\varepsilon$-caprolactone)/Poly $(\varepsilon$ caprolactone) Nanofibrous Scaffolds for Retinal Tissue Engineering. Int. J. Nanomed. 2011, 6, 453-461.

(23) Wade, R. J.; Bassin, E. J.; Rodell, C. B.; Burdick, J. A. ProteaseDegradable Electrospun Fibrous Hydrogels. Nat. Commun. 2015, 6, 6639.

(24) Zamani, F.; Amani-Tehran, M.; Latifi, M.; Shokrgozar, M. A. The Influence of Surface Nanoroughness of Electrospun PLGA Nanofibrous Scaffold on Nerve Cell Adhesion and Proliferation. J. Mater. Sci.: Mater. Med. 2013, 24, 1551-1560.

(25) Azad, A.-M. Fabrication of Yttria-Stabilized Zirconia Nanofibers by Electrospinning. Mater. Lett. 2006, 60, 67-72.

(26) Biswas, A.; Park, H.; Sigmund, W. M. Flexible Ceramic Nanofibermat Electrospun from $\mathrm{TiO} 2-\mathrm{SiO} 2$ Aqueous sol. Ceram. Int. 2012, 38, 883-886.

(27) Adams, J. W.; Ruh, R.; Mazdiyasni, K. Young's Modulus, Flexural Strength, and Fracture of Yttria-Stabilized Zirconia versus Temperature. J. Am. Ceram. Soc. 1997, 80, 903-908.

(28) Chaim, R.; Hefetz, M. Effect of Grain Size on Elastic Modulus and Hardness of Nanocrystalline $\mathrm{ZrO}_{2}-3 \mathrm{wt} \% \mathrm{Y}_{2} \mathrm{O}_{3}$ Ceramic. J. Mater. Sci. 2004, 39, 3057-3061.

(29) Ramesh, S.; Meenaloshini, S.; Tan, C.; Chew, W. K.; Teng, W. Effect of Manganese Oxide on The Sintered Properties and Low Temperature Degradation of Y-TZP Ceramics. Ceram. Int. 2008, 34, $1603-1608$

(30) Xu, S.; Shi, Y.; Kim, S. G. Fabrication and Mechanical Property of Nano Piezoelectric Fibers. Nanotechnology 2006, 17, 4497-4501.

(31) Lee, S.-H.; Tekmen, C.; Sigmund, W. M. Three-Point Bending of Electrospun TiO2 Nanofibers. Mater. Sci. Eng., A 2005, 398, 77-81.

(32) Wang, J.; Binner, J.; Vaidhyanathan, B.; Joomun, N.; Kilner, J.; Dimitrakis, G.; Cross, T. E. Evidence for The Microwave Effect During Hybrid Sintering. J. Am. Ceram. Soc. 2006, 89, 1977-1984.

(33) Xie, Z.; Yang, J.; Huang, X.; Huang, Y. Microwave Processing and Properties of Ceramics with Different Dielectric Loss. J. Eur. Ceram. Soc. 1999, 19, 381-387.

(34) Sundaresan, S. G.; Rao, M. V.; Tian, Y.-1.; Ridgway, M. C.; Schreifels, J. A.; Kopanski, J. J. Ultrahigh-Temperature Microwave Annealing of $\mathrm{Al}^{+}$- and $\mathrm{P}^{+}$-implanted 4H-SiC. J. Appl. Phys. 2007, 101, 073708.

(35) Goldstein, A.; Travitzky, N.; Singurindy, A.; Kravchik, M. Direct Microwave Sintering of Yttria-Stabilized Zirconia at $2.45 \mathrm{GHz}$. J. Eur. Ceram. Soc. 1999, 19, 2067-2072.

(36) Watari, S.; Hayashi, K.; Wood, J. A.; Russell, P.; Nealey, P. F.; Murphy, C. J.; Genetos, D. C. Modulation of Ssteogenic Differ- 
entiation in hMSCs Cells by Submicron Topographically-Patterned Ridges and Grooves. Biomaterials 2012, 33, 128-136.

(37) Pot, S. A.; Liliensiek, S. J.; Myrna, K. E.; Bentley, E.; Jester, J. V.; Nealey, P. F.; Murphy, C. J. Nanoscale Topography-Induced Modulation of Fundamental Cell Behaviors of Rabbit Corneal Keratocytes, Fibroblasts, and Myofibroblasts. Invest. Ophthalmol. Visual Sci. 2010, 51, 1373-1381.

(38) McNamara, L. E.; McMurray, R. J.; Biggs, M. J.; Kantawong, F.; Oreffo, R. O.; Dalby, M. J. Nanotopographical Control of Stem Cell Differentiation. J. Tissue Eng. 2010, 1, 120623.

(39) Nandakumar, A.; Yang, L.; Habibovic, P.; van Blitterswijk, C. Calcium Phosphate Coated Electrospun Fiber Matrices as Scaffolds for Bone Tissue Engineering. Langmuir 2010, 26, 7380-7387.

(40) Fernandes, H.; Mentink, A.; Bank, R.; Stoop, R.; van Blitterswijk, C.; de Boer, J. Endogenous Collagen Influences Differentiation of human Multipotent Mesenchymal Stromal Cells. Tissue Eng., Part A 2010, 16, 1693-1702.

(41) Nandakumar, A.; Barradas, A.; de Boer, J.; Moroni, L.; van Blitterswijk, C.; Habibovic, P. Combining Technologies to Create Bioactive Hybrid Scaffolds for bone tissue engineering. Biomatter 2013, 3, e23705.

(42) Chuah, Y. J.; Zhang, Y.; Wu, Y.; Menon, N. V.; Goh, G. H.; Lee, A. C.; Chan, V.; Zhang, Y.; Kang, Y. Combinatorial Effect of Substratum Properties on Mesenchymal Stem Cell Sheet Engineering and Subsequent Multi-Lineage Differentiation. Acta Biomater. 2015, $23,52-62$.

(43) Gaharwar, A. K.; Mihaila, S. M.; Swami, A.; Patel, A.; Sant, S.; Reis, R. L.; Marques, A. P.; Gomes, M. E.; Khademhosseini, A. Bioactive Silicate Nanoplatelets for Osteogenic Differentiation of human Mesenchymal Stem Cells. Adv. Mater. 2013, 25, 3329-3336.

(44) Polini, A.; Pisignano, D.; Parodi, M.; Quarto, R.; Scaglione, S. Osteoinduction of Human Mesenchymal Stem Cells by Bioactive Composite Scaffolds Without Supplemental Osteogenic Growth Factors. PLoS One 2011, 6, e26211.

(45) Yuan, H.; Fernandes, H.; Habibovic, P.; de Boer, J.; Barradas, A. M.; de Ruiter, A.; Walsh, W. R.; van Blitterswijk, C. A.; de Bruijn, J. D. Osteoinductive Ceramics As a Synthetic Alternative to Autologous Bone Grafting. Proc. Natl. Acad. Sci. U. S. A. 2010, 107, 13614-13619.

(46) Gauthier, O.; Bouler, J.-M.; Aguado, E.; Pilet, P.; Daculsi, G. Macroporous Biphasic Calcium Phosphate Ceramics:Influence of Macropore Diameter and Macroporosity Percentage on Bone Ingrowth. Biomaterials 1998, 19, 133-139.

(47) Scotti, C.; Tonnarelli, B.; Papadimitropoulos, A.; Scherberich, A.; Schaeren, S.; Schauerte, A.; Lopez-Rios, J.; Zeller, R.; Barbero, A.; Martin, I. Recapitulation of Endochondral Bone Formation Using Human Adult Mesenchymal Stem Cells As a Paradigm for Developmental Engineering. Proc. Natl. Acad. Sci. U. S. A. 2010, 107, $7251-7256$.

(48) Gerstenfeld, L.; Shapiro, F. Expression of Bone-Specific Genes by Hypertrophic Chondrocytes: Implications of the Complex Functions of the Hypertrophic Chondrocyte during Endochondral Bone Development. J. Cell. Biochem. 1996, 62, 1-9.

(49) Kitagawa, F.; Takei, S.; Imaizumi, T.; Tabata, Y. Chondrogenic Differentiation of Immortalized Human Mesenchymal Stem Cells on Zirconia Microwell Substrata. Tissue Eng., Part C 2013, 19, 438-448.

(50) Curtin, C. M.; Cunniffe, G. M.; Lyons, F. G.; Bessho, K.; Dickson, G. R.; Duffy, G. P.; O’Brien, F. J. Innovative Collagen NanoHydroxyapatite Scaffolds Offer a Highly Efficient Non-Viral Gene Delivery Platform for Stem Cell-Mediated Bone Formation. Adv. Mater. 2012, 24, 749-754.

(51) Kim, H. W.; Kim, H. E.; Knowles, J. C. Production and Potential of Bioactive Glass Nanofibers as a Next-Generation Biomaterial. Adv. Funct. Mater. 2006, 16, 1529-1535.

(52) Takeuchi, K.; Saruwatari, L.; Nakamura, H. K.; Yang, J. M.; Ogawa, T. EnhancedIntrinsic Biomechanical Properties of Osteoblastic Mineralized Tissue on Roughened Titanium Surface. J. Biomed. Mater. Res., Part A 2005, 72A, 296-305.

(53) Tang, M.; Chen, W.; Liu, J.; Weir, M. D.; Cheng, L.; Xu, H. H. Human Induced Pluripotent Stem Cell-Derived Mesenchymal Stem
Cell Seeding on Calcium Phosphate Scaffold for Bone Regeneration. Tissue Eng., Part A 2014, 20, 1295-1305.

(54) DiGirolamo, C. M.; Stokes, D.; Colter, D.; Phinney, D. G.; Class, R.; Prockop, D. J. Propagation and Senescence of Human Marrow Stromal Cells in Culture: a Simple Colony-Forming Assay Identifies Samples with the Greatest Potential to Propagate and Differentiate. Br. J. Haematol. 1999, 107, 275-281.

(55) Phinney, D. G.; Kopen, G.; Righter, W.; Webster, S.; Tremain, N.; Prockop, D. J. Donor Variation in the Growth Properties and Osteogenic Potential of Human Marrow Stromal cells. J. Cell. Biochem. 1999, 75, 424-436.

(56) Gregory, C. A.; Gunn, W. G.; Peister, A.; Prockop, D. J. An Alizarin Red-Based Assay of Mineralization by Adherent Cells in Culture: Comparison with Cetylpyridinium Chloride Extraction. Anal. Biochem. 2004, 329, 77-84. 